\title{
Columbia Ground Squirrel in Subalpine Forest Openings in Central Idaho
}

\author{
RON LAMBETH AND M. HIRONAKA
}

\begin{abstract}
Columbia ground squirrels were studied in natural alpine forest openings. Three sites were selected having the same potential but presently with different vegetation due to differing levels of past domestic sheep use. Ground squirrel population was least in the light-use area and increased with vegetation change induced by increased sheep use. Juveniles were most plentiful in the mediumuse site and least in the heavy-use area. Up to a point, ground squirrel population increased with plant retrogression. With continued retrogression the community became less suitable to support a healthy population because of less preferred forage species. Lupinus sericeus was the most preferred forb. Other species included $\boldsymbol{A}$ chillea millefolium and Descurania richardsonii, species not generally preferred by sheep. The discussion of sheepground squirrel relative impacts also considers metabolic requirement, grazing period and animal density of both grazers.
\end{abstract}

Natural forest openings in the subalpine zone provide the bulk of the forage on domestic sheep summer range in central Idaho. In these openings Columbia ground squirrels (Citellus columbianus) are readily observed as they forage and sit up near burrow entrances, quietly observing their surroundings and darting into the safety of the burrow when alarmed by unfamiliar sound or movement. The foraging activity is confined to daylight hours during the growing season. Depending on locality, these animals hibernate for 7 or 8 months (Shaw 1926). The adult ground squirrel weighs about a pound $(450 \mathrm{~g})$, with males outweighing females.

Observations suggest that the Columbia ground squirrel competes for the same forage utilized by domestic sheep on the summer range. Other studies have indicated that ground squirrel populations increase with livestock grazing primarily because changes in composition and structure of the vegetation provide greater visibility for the small animal (Smith 1940, Howard and Childs 1959).

Because of the importance of the subalpine forest openings for domestic sheep grazing and the association of these openings to the Columbia ground squirrel, it is important that the interrelationships are better understood. The purpose of this study was to determine the diet of the Columbia ground squirrel, its effect(s) on plant communities and population response in relation to domestic sheep grazing.

\section{Area of Study}

The study was conducted in the Idaho batholith portion of the Payette National Forest in central Idaho. This batholith is the largest granitic intrusion in the United States and occupies nearly 16,000 square miles. The terrain is extremely rugged, with uplifting and faulting and mountain glaciation determining the land contour. Long, steep-flanked ridges with occasional peaks characterize this mountainous area. Elevational extremes range from $550 \mathrm{~m}$ $(1800 \mathrm{ft}) \mathrm{MSL}$ to peaks of $2725 \mathrm{~m}$ (9000 ft) MSL (Thompson 1973).

\footnotetext{
R. Lambeth is presently with the Bureau of Land Management, Grand Junction, Colorado.

This paper is published with the approval of the Director, Forest, Wildlife, and Range Experiment Station, University of Idaho, Moscow 83843, as Contribution No. 236. This study was supported in part from Mclntire-Stennis funds.

Manuscript received November $17,1980$.
}

Annual precipitation, mostly in the form of snow, ranges from $635 \mathrm{~mm}$ to more than $1400 \mathrm{~mm}$ ( 25 to $55 \mathrm{in}$.). Sporadic, high intensity, short duration summer thunderstorms are moderately frequent. The growing season is less than 60 days at $1800 \mathrm{~m}(6000$ $\mathrm{ft}$ ), while frost may occur any night during the summer.

The short growing season, the coarse plant material and youthfulness of the geomorphology have restricted soil development. Entisols and Inceptisols dominate.

The extreme climatic and elevational gradients are responsible for the numerous vegetational zones in the Idaho batholith. At the lower elevations, true Palouse bunchgrass occurs. With increasing elevation, the vegetational series encountered are ponderosa pine, Douglas-fir, grand fir, Engelmann spruce-fir, and the subalpine fir-whitebark pine (Daubenmire 1970, Evans and Tisdale 1972, Steele et al. 1975). Eighty percent of the batholith is coniferous forest. The subalpine fir-whitebark pine zone is relatively small in total area yet is of primary importance for sheep summer range. Applicability of research findings to other areas of the batholith was a prime consideration in selection of study area.

\section{Methods}

The study was conducted in forest openings associated with the subalpine fir-whitebark pine series at about the $2275 \mathrm{~m}(7500 \mathrm{ft})$ MSL. Three openings were selected on the basis of known sheep grazing histories, i.e., lightly used, heavily used bedding ground and a moderately utilized opening. The historic use was not measured, but was determined through communication with U.S. Forest Service personnel. In the year of study there was no grazing by sheep. The medium and heavy-use areas generally had been grazed every year and the light-use area one year in two. All three sites were in the same grazing allotment. All sites were southerly exposed with slopes ranging from 12 to $38 \%$ and with similar granitic parent material. The original vegetation was thus judged to be essentially the same for the three sites.

At each site, two contiguous $50 \times 50 \mathrm{~m}(165 \times 165 \mathrm{ft})$ plots were delineated. One of the two plots was randomly selected for intensive vegetation sampling. The other was used for live trapping of ground squirrels.

\section{Vegetation Sampling}

Vegetation was sampled for foliage cover by species as determined by a vertical 10-point frame (Goodall 1952) with 50 random placements at each of the three sites. Sampling was done in July at the peak flowering of the most species. Yield was determined by individual species in ten $.10 \mathrm{~m}^{2}\left(.96 \mathrm{ft}^{2}\right)$ randomly located plots. Yield is reported as oven-dried $\left(70^{\circ} \mathrm{C}\right)$.

\section{Ground Squirrel Sampling}

Columbia ground squirrel population data were gathered from $10 \times 10 \times 40 \mathrm{~cm}(4 \times 4 \times 16 \mathrm{in}$.) live traps placed in a grid pattern of 3 across the plot by 4 down, making 12 traps per plot. Traps were operated for a 24-hour period before removal to another site. The same site was resampled every third day. The traps were checked twice daily, noon and sunset. All capture points were mapped. 
Captured squirrels were removed to a handling cone, sexed, weighed, marked with black hair dye on aduits and $5 \%$ picric acid solution on juveniles (young of the year), and then released. Recaptured animals were weighed and, if needed, the markings were refreshed before release. Fecal pellets in traps were collected and salted for preservation. Fecal samples of adults were composited daily by site; those of juveniles constituted a separate sample. At the end of the population sampling, ten individuals were sacrificed for stomach and colon content comparison. This was to test the reliability of the microscopic fecal analysis that was to be made later. The trapping period was from July 17 to August 21 and again on September 7. Reference plant material for microscopic fecal a nalysis was collected.

\section{Dietary Analysis}

The microscopic technique of diet analysis is well known (Brusven and Mulkern 1960, Storr 1961, Sanders et al. 1980). Microscopic slides were prepared from identified reference plants in the manner described by Cavender and Hansen (1970).

The Wiley mill was used to grind fecal and stomach samples to be analyzed. Reference plant materials were also ground in the Wiley mill to make them of uniform particle size with that in the fecal and stomach samples. From this material $8 \mathrm{mg}$ aliquants were taken for quantitative reference slides. For each of these reference plant species there was a known weight of material spread over a standard area the size of the cover of glass. Quantitative reference slides were made separately for the floral and leaf parts of most species.

The type of epidermal tissue fragment selected as diagnostic for each species appeared on the respective quantitative reference slides in the frequency range of $45-75$ percent of the observed microscope fields. Frequencies were converted to density values expected under random conditions according to Fracker and Brischle (1944). The relationship between density and weight is linear (Sparks and Malechek 1968). By knowing the microscope field frequencies of those diagnostic fragments on the reference slides, where the quantity of each species is equal, relative percentages of these species occurring in the fecal samples could be estimated within $80 \%$ of their actual values.

\section{Results}

\section{Vegetation}

The three sites in which ground squirrel populations were sampled previously supported the same climax vegetation but the vegetation of each had been modified to different degrees by past sheep use. The vegetational data were analyzed to establish the relationship between successional stages in vegetation and ground squirrel populations.

As determined by Kulcynski's Similarity Index (Oosting 1956) the forest openings that were lightly and medially utilized were vegetationally $50 \%$ similar to each other, whereas they were only 8 and $16 \%$, respectively, similar to the heavily used area. The medially utilized area possessed the greatest species richness, but the lightly grazed area had the greatest dominance diversity using the Shannon Index (Clifford and Stevenson 1975). Shaffi and Yarranton (1973) imply that species evenness is more closely correlated with plant succession than was species richness. Figure 1 illustrates the nature of the dominance diversity index of the three areas. Most the plant cover was provided by a few species. On the heavily utilized area, western needlegrass (Stipa occidentalis) made up $62 \%$ of the plant cover. Elk sedge (Carex geyerii) was the most abundant species on the medially utilized area, occupying $36 \%$ of the plant cover. On the lightly grazed area, wandering daisy (Erigeron peregrinus) had the greatest cover at $14 \%$. The high dominance diversity index indicates that dominance was shared by several species on the lightly utilized area.

Margalef (1958) declared that indices of diversity in biotic communities increase toward the climax state. He added that when "the final tendencies are predominant" the indices will diminish. Considering plant composition, the least similarity existed bet ween the

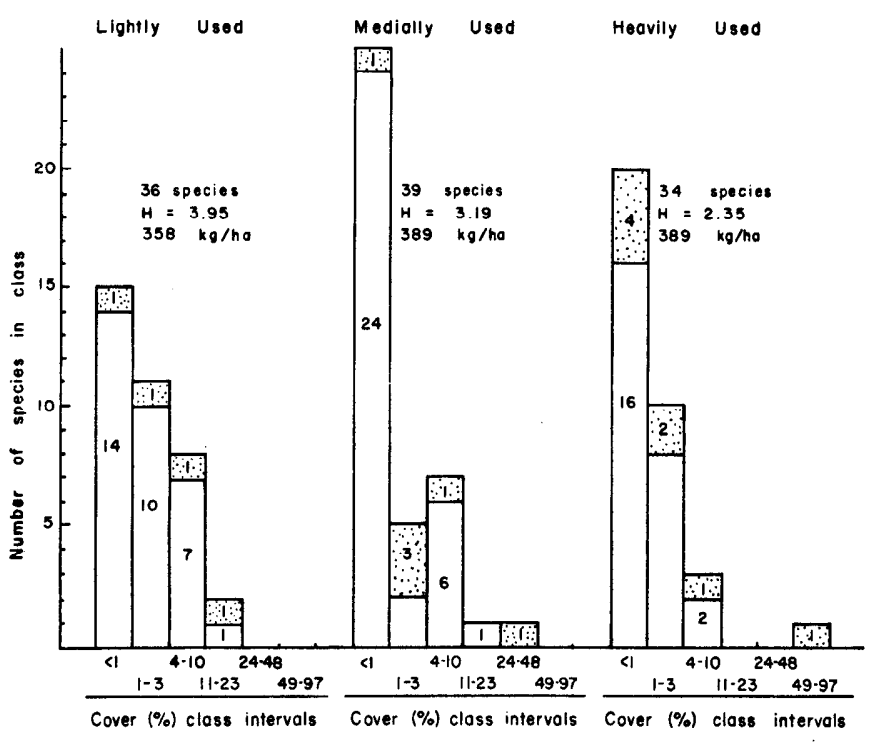

Fig. 1. Number of species present in different cover classes (increasing by Log:), total yield and Shannon-Weaver Diversity Index $\left(H^{\prime}\right)$ of 3 subalpine forest opening communities with different past levels of domestic sheep use. The number of grass and grasslike species are given in the stippled area of the columns; the number forbs are presented in the unstippled area.

lightly grazed and the heavily grazed sites, placing them at extremes to each other. Following the descending diversity indices for the plant communities, the three sites move down the successional gradient from the lightly grazed to the medially grazed to the heavily grazed field. All three sites appear well below the point of predominant "final tendencies." The pathway back to climax would be expected to lead the lower series through the stages resembling the present condition of the lightly grazed area with removal of the grazing stress.

Herbage production was similar at all three areas. This lack of correlation between herbage yield and degree of disturbance is not unusual, however. Klemmedson and Smith (1964) reported cheatgrass (Bromus tectorum) may outyield native species in years with favorable conditions. Mule's ear (Wyethia amplexicaulis) is a species that has increased in some areas with cattle grazing. In the Targhee National Forest in Idaho, control of the species resulted in significantly less total herbage but increases considerably the usa-

Table 1. Population characteristics of Columbia ground squirrels on three sites ( $1 / 4$ hectare) distinguished by the historic intensity of grazing by domestic sheep. July 17-September 7, 1975.

\begin{tabular}{|c|c|c|c|}
\hline \multirow[b]{2}{*}{ Parameter } & \multicolumn{3}{|c|}{ Site } \\
\hline & $\begin{array}{l}\text { Light } \\
\text { use }\end{array}$ & $\begin{array}{c}\text { Medial } \\
\text { use }\end{array}$ & $\begin{array}{c}\text { Heavy } \\
\text { use }\end{array}$ \\
\hline $\begin{array}{l}\text { Population indices } \\
\text { Lincoln index }{ }^{1} \\
\text { Field Count Index }{ }^{2} \\
\text { Burrow Density } 50 \text { sq meters } \\
\text { Mean distance between capture } \\
\text { points }{ }^{3}\end{array}$ & $\begin{array}{c}14.7 \\
\text { none seen } \\
2 \\
24 \mathrm{~m} \pm 9.8\end{array}$ & $\begin{array}{c}22.5 \\
16 \\
4 \\
22 \mathrm{~m} \pm 2.7\end{array}$ & $\begin{array}{c}25.0 \\
16 \\
5 \\
15 \mathrm{~m} \pm 9.3\end{array}$ \\
\hline $\begin{array}{l}\text { Other populations characters } \\
\text { Percent juvenile } \\
\text { Percent female } \\
\text { Mean weight }(\mathrm{g}) \text {, males } \\
\text { Mean weight }(\mathrm{g}) \text {, females } \\
\text { Average adult rate of weight gains }\end{array}$ & $\begin{array}{c}7.7 \\
42.1 \\
461 \\
361 \\
2.67 \mathrm{~g} / \text { day }\end{array}$ & $\begin{array}{c}33.3 \\
79.3 \\
474 \\
416 \\
3.03 \mathrm{~g} / \text { day }\end{array}$ & $\begin{array}{c}0.0^{4} \\
40.6 \\
468 \\
467 \\
1.78 \mathrm{~g} / \text { day }\end{array}$ \\
\hline
\end{tabular}

'See Giles (1969).

2Ratio of animals seen over those to be marked $X$ total known to be marked.

${ }^{3}$ The distance individual animals were recaptured from the previous points of capture. ${ }^{4}$ None were captured; 2 were seen Sept. 7.

${ }^{3}$ Based on average weight differences of recaptured animals during period of study. 
ble forage and improved range condition (Mueggler and Blaisdell 1951).

\section{Ground Squirrel Population}

Ninety-seven squirrels were trapped on the three sites. A males to females ratio of 53:47 among adults and 50:50 among juveniles were found. This suggests that the inferences from the trapping data do not have a sex bias in that a 50:50 ratio is expected. The mean adult weight was $451 \mathrm{~g} \pm 18$ (P.95). Females averaged 90 percent of the mean male weight. Table 1 provides a summary of population data for the ground squirrels of the three areas. The four population estimate indicators show that the medially and heavily grazed sites supported larger populations of ground squirrel than the lightly used area.

The Lincoln index (Giles 1969) has a weakness in that if captured animals become "trap shy" the index tends to overestimate the population. Underestimates result when the animals become "trap happy"(Balph 1968). However, in comparing relative populations among sites, the Lincoln index is highly satisfactory because opposing behavior is not likely to prevail in animals in a localized area.

The field count index used the known number of marked individuals to derive an estimate of population based upon the ratio of total observed over those that were marked. This technique reduced the bias associated with retrapping techniques, but required more manpower. No animal was observed during the visual sampling periods on the lightly grazed site, and the general impression was that fewer ground squirrels were actually present as compared to the other two areas.

The density of ground squirrel burrow holes and mounds were counted in a $1 \times 50-\mathrm{m}$ transect and yielded supportive evidence that the lightly grazed site contained the lowest population and the medially and heavily grazed had considerably more activity.
Futhermore, the mean-distance-between-capture-points technique also supported the results of the other methods. The mean distance between capture points of ground squirrels caught more than once was greatest on the lightly grazed site and least on the heavily grazed site. As animals increase in population density, the foraging distance of each individual is likely to decrease. The indications from all data sources are that Columbia ground squirrels have increased with increased levels of sheep grazing.

\section{Sex Ratio}

Sex ratio may be an indicator of animal productivity. The medially grazed area would appear to be the most productive because it had the highest percentage of females and juveniles present. On the heavily grazed site, the unsuccessful capture of juveniles (two were seen but not captured) suggested that the females were barren or experiencing delayed pregnancies. The latter explanation was discounted because observations continued through early September. Although the adult population was high on the heavily utilized area, the low number of juveniles was suggestive that the habitat was marginal for reproduction.

\section{Rate of Gain}

Daily gain of individual ground squirrels was lea rned by dividing the number of days between capture time and recapture time into the change in weight between capture and recapture. The average daily gain of adults was lowest in the heavily grazed area. A daily gain of $1.78 \mathrm{~g} /$ day for adults in the heavily utilized area was calculated as compared to $3.03 \mathrm{~g} /$ day and $2.67 \mathrm{~g} /$ day in the medially and lightly grazed areas, respectively. The more advanced age of the population (more than 2 years old) in the heavily grazed area is likely the reason for the low daily gain (Shaw 1945).

The data suggest that the optimum habitat for subalpine Columbia ground squirrel is more closely allied with medially grazed range than either lightly or heavily utilized range.

Table 2. Relative Preference Index (RPI)1 of plant species as indicated in the diets of Columbia ground squirrels on three subalpine sites under different levels of grazing by sheep, central Idaho batholith, July 17-September 7, 1975.

\begin{tabular}{|c|c|c|c|c|c|c|c|}
\hline \multirow[b]{2}{*}{ Species! } & \multirow[b]{2}{*}{$\begin{array}{l}\text { Preferred } \\
\text { portions }\end{array}$} & \multicolumn{2}{|c|}{ Lightly used } & \multicolumn{2}{|c|}{ Medially used } & \multicolumn{2}{|c|}{ Heavily used } \\
\hline & & $\%$ cover & RPI & $\%$ cover & RPI & $\%$ cover & RPI \\
\hline Grasses \& grass-likes & & 17.2 & 1.29 & 43.6 & 0.41 & 70.8 & 0.32 \\
\hline Bromus carinatus & lvs, fr & 0.0 & - & 1.2 & 0.25 & 1.1 & 3.09 \\
\hline Carex spp. & fr & 0.0 & - & 0.0 & - & 6.7 & 0.79 \\
\hline Carex geyeri & $\mathrm{fr}$ & 10.9 & 1.00 & 36.0 & 0.33 & 0.4 & 0.00 \\
\hline Melica bulbosa & lvs, fr & 5.3 & 1.83 & 1.2 & 0.75 & 0.0 & - \\
\hline Poa pratensis & lvs, fr & 1.1 & 0.00 & $<0.4$ & 0.00 & 0.4 & - \\
\hline Stipa occidentalis & fr & $<0.3$ & $?$ & 4.0 & 1.15 & 62.5 & 0.10 \\
\hline Forbs & & & 82.8 & 0.94 & 56.4 & 1.46 & 29.2 \\
\hline Achillea millefolium & Ivs & 0.7 & 2.29 & 4.5 & 0.60 & 4.5 & 4.07 \\
\hline Antennaria microphylla & & $<0.3$ & $>1.67$ & $<0.4$ & \pm 0.75 & 0.7 & 2.71 \\
\hline Arenaria congesta & fls & $<0.3$ & $>2.33$ & 4.5 & 0.49 & 1.5 & 1.80 \\
\hline Balsamorhiza sagittata & lvs & 6.7 & 0.24 & 0.0 & - & 0.0 & - \\
\hline Cryptantha torreyana & & 0.0 & - & 0.0 & - & 5.6 & 0.14 \\
\hline Descurainia richardsonii & lvs, fls, fr & $<0.3$ & 0.00 & $<0.4$ & \pm 0.25 & 3.0 & 4.23 \\
\hline Erigeron foliosus & lvs, fls & 7.7 & 0.92 & 8.5 & 0.14 & 0.0 & - \\
\hline E. subtrinervis & lvs, fls & 3.9 & 1.00 & $<0.4$ & $>5.25$ & 0.0 & - \\
\hline Fragaria virginiana & & 1.1 & 0.00 & 0.0 & - & 2.2 & 0.27 \\
\hline Gayophytum humile & fls & $<0.3$ & $>9.00$ & $<0.4$ & $>9.00$ & 0.4 & 0.06 \\
\hline Hieracium albertinum & lbs, fls & 2.1 & 3.00 & 2.0 & 1.10 & 0.0 & - \\
\hline Linanthastrum nuttallii & & 0.0 & - & $<0.4$ & $>0.02$ & 0.4 & 0.05 \\
\hline Lupinus sericeus & lvs, fls & 8.8 & 4.18 & 11.7 & 4.57 & 0.0 & - \\
\hline Monolepsis nutalliana & & 0.0 & - & 0.0 & - & 0.4 & 0.50 \\
\hline Penstemon spp. & fls & 8.4 & 0.00 & 2.8 & 0.50 & 3.4 & 0.26 \\
\hline Phlox pulvinata & fls & 1.1 & 8.09 & 6.5 & 1.28 & 2.6 & 3.00 \\
\hline Polygonum douglasii & fls & $<0.3$ & $?$ & $<0.4$ & 1.75 & 0.4 & 1.50 \\
\hline Ranunculus uncinatus & & 0.0 & - & 0.0 & - & 1.9 & 0.58 \\
\hline
\end{tabular}

IRPI $=\frac{\% \text { of the diet }}{\% \text { of total plant cover }}$.

2Species are not included which do not appear in the diet or percent cover in suncient quantities on at least one site for RPI to be computed.

3Relative percent plant cover. 


\section{Dietary Habits}

Forty-three plant species were identified in the diet of Columbia ground squirrel during July 17 through September 7 , the period of maximum activity. The term spanned a period from 2 weeks prior to emergence of juvenile squirrels to the autumn curing of the vegetation. Nineteen of the 43 species contributed $1 \%$ or more to the ground squirrel diet. The coefficient of variation of each species contributing to the diet was substantial and averaged $112 \%$ as compared to $75 \%$ reported by Hubbard and Hansen (1976). Their sample was composed of a composite of at least 50 subsamples, whereas in the study 5 fecal subsamples were composited into a sample.

The preference of plant species by ground squirrels is suggested by the relative preference index (RPI), which is expressed as the ratio between the percent in the diet (as determined by fecal analysis) in relation to the percent it is present in the community. Values greater than 1.0 are indicative of positive animal preference. One needs to be aware that the RPI value can be misleading as there may be considerable sampling error in the diet and vegetation analysis. Furthermore, the magnitude of the value might be affected by how much as well as what else is present in the community. However, if the R PI value is consistently higher or lower than 1.0, it does provide a basis for a statement of animal preference.

Forage availability was sampled once near the middle of the trapping period. During this period ground squirrels selected forbs in greater percentages than were present in the medially and heavily grazed areas ( $\mathrm{RPI}=1.46$ and 2.65 respectively) (Table 2 ). Forbs predominated in the diet on the lightly grazed area also, but the grasses were taken in slight excess of percentage available. Because forbs are highly preferred by sheep, the reported observations of higher Columbia ground squirrel populations on grazed areas appear contradictory from a dietary standpoint.

Silky lupine (Lupinus sericeus) was the most heavily used species and constituted $29 \%$ of the diet. Sedges were almost as important as grasses, 9 and $12 \%$ respectively. Only the floral part of the sedges was taken, however.

Similarity of diet with plant availability was highest in the medially grazed area where animal fecundity and weight gains per day were highest. Yarrow (Achillea millefolium) had equal cover values on the medially and heavily used areas, yet was distinctly preferred on the latter area. Silky lupine was lacking on the latter area, however. Ballhead sandwort (Arenaria congesta) and mountain brome (Bromus carinatus) also had higher RPI's on the heavily grazed area. These plants appear to be secondary in palatability to silky lupine. In the same way, several species that the animals selected on the lightly grazed site were of lower preference on the medially grazed site. These were western hawkweed (Hieracium albertinum) and cushion phlox (Phlox pulvinata). Elk sedge (Carex geyeri) was consumed according to its abundance on site. At the other extreme, Erigeron peregrinus composed 14.0 and $5.3 \%$ of the cover on the lightly and medially grazed sites, respectively, but did not occur in the diet of any ground squirrel.

\section{Discussion}

This study indicates that the Columbia ground squirrel populations respond more directly to changes in forage quality than to changes in vegetation structure brought about by sheep grazing. It is reasonable to assume that the lightest grazed areas would retain the highest composition of palatable species to sheep. All three study areas had approximately the same plant productivities, yet the lowest ground squirrel population was on the area of historic light use by sheep. This suggests that the dietary habits of sheep and these ground squirrels do not coincide.

The taller, though less dense, vegetation on the lightly grazed site does raise questions. Was the population of ground squirrels in fact high, but capture rates low due to the difficulty in visually attracting the squirrels to traps (Balph 1968)? A low population for the site was accepted, because all four population indices agree, includ- ing the burrow density count, which was unaffected by vegetation height. Was the population lowest here due to the visual advantages to predators? Forage quality is given more importance, because Columbia ground squirrels were also frequently found in the timber where the understory included a variety of palatable herb species, and vision was far more obscured than any of the study sites. Average ground squirrel weight was lowest on the site of light sheep use. Diet and site floristics were less similar and likewise animal weight gains were less on the lightly grazed site than on the medium use site. Thus, up to a point, forage quality for the ground squirrel apparently is improved with sheep grazing.

With the mean weight of $451 \mathrm{~g}$ from this study, one can calculate the approximate animal equivalence of Columbia ground squirrel to sheep. A 1-pound ground squirrel requires more calories per unit of body weight than would a 150-pound sheep. Based on McNab's (1963) equation, $70 W^{0.75}, 42$ adult Columbia ground squirrels would be equivalent to one 150-pound sheep. Assuming that a sheep remains in an area for 3 days and a Columbia ground squirrel forages in the same area for 120 days, .95 ground squirrel is able to utilize the amount of forage in one season that sheep would in 3 days. Essentially this means that under realistic grazing periods on the home range of a ground squirrel, one squirrel is equivalent to one sheep in the amount of forage removed.

The Columbia ground squirrel to sheep equivalence calculated in this study is less than one half of that reported by Shaw (1920) and Stoddart et al. (1975). Shaw estimated that 96 Columbia ground squirrels equal one sheep. In Shaw's study daily consumption averaged 17.5 percent of their body weight. Body weight in the present study averaged about $450 \mathrm{~g}$, which would compute to a consumption rate of about $80 /$ gday. With his figures, an equivalence of 30-40 Columbia ground squirrels to one sheep would be more realistic.

Differences in dietary habits of sheep and ground squirrel would lessen the apparent competition for forage. The ground squirrel's preference for silky lupine is interesting. This lupine is responsible for congenital deformities known as "crooked calf disease" and is a major plant toxic to sheep (James and Johnson 1976). In addition to silky lupine, Descurania richardsonii and Achillea millefolium were preferred by ground squirrels and not by sheep, whereas Polygonum phytolacceafolium appeared to be avoided by both. Phlox pulvinata was one species that was preferred by both animals (Garechana 1979).

It is concluded that sheep grazing has increased ground squirrel numbers in the Idaho batholith. On subalpine meadows where ground squirrels are numerous, the squirrels become an influence as important as sheep upon the plant community. However, the somewhat complementary nature of sheep and ground squirrel diets may retard or even prevent the ecological retrogression of the pasture as long as the productivity of the land adequately exceeds utilization by all plant consumers.

\section{Literature Cited}

Balph, D.F. 1968. Behavioral responses of unconfined Uinta ground squirrels to trapping. J. Wildl. Manage. 32:778-794.

Brusven, M.A., and G.B. Mulkern. 1960. The use of epidermal characteristics for the identification of plants recovered in fragmentary condition from crops of grasshoppers. North Dakota Agr. Exp. Sta. Res. Rep. No. 3. $11 \mathrm{p}$.

Cavender, B.R., and R.M. Hansen. 1970. The microscope method used for herbivore diet estimates and botanical analysis of litter and mulch at the Pawnee site. IBP Grassland Biome. Tech. Rep. No. 18. 9 p.

Clifford, H.T., and W. Stephenson. 1975. An introduction to numerical classification. Acad. Press. N.Y. 229 p.

Daubenmire, R. 1970. Steppe vegetation of Washington. Washington Agr. Exp. Sta. Tech. Bull. No. 62.131 p.

Elliot, C.L., and J.T. Flinders. 1979. Seasonal home range of a colony of Columbia ground squirrels in the Idaho primitive area. J. Idaho Acad. Sci. 15:53-55. 
Evans, G.R., and E.W. Tisdale. 1972. Ecological characteristics of Aristido longesta and Agropyron spicatum in west-central Idaho. Ecology 53:137-142.

Fracker, S.B., and J.A. Brischle. 1944. Measuring the local distribution of Ribes. Ecology 25:283-303.

Garechana, B. 1979. Effects of sheep use on subalpine bedyrounds in the Idaho batholith. M.S. thesis. Univ. of Idaho, Moscow. $97 \mathrm{p}$.

Giles, R. Jr. (Ed.). 1969. Wildlife management techniques. 3rd ed. The Wildlife Society. Washington, D.C. 623 p.

Goodall, D.W. 1952. Point quadrats in analysis of vegetation. Aust. J. Sci. Res. (series B. Biol. Sci. 5:1-41.

Howard, W.E., and H.E. Childs, Jr. 1959. Ecology of pocket gophers with emphasis on Thomomys bottae mewa. Hilgardia 29:277-358.

Hubbard, R.L., and R.M. Hansen. 1976. Diets of wild horses, cattle and mule deer in the Piceance Basin, Colorado. J. Range Manage. 29: 389-392.

James, L.F., and A.E. Johnson. 1976. Some major plant toxicities of the western United States. J. Range Manage. 29:356-363.

Klemmedson, J.O., and J.G. Smith. 1964. Cheatgrass (Bromus tectorum L.) Bot. Rev. 30:226-262.

Lambeth, R.E. 1977. The Columbia ground squirrel in subalpine forest openings in the Idaho batholith. M.S. thesis. Univ. of Idaho, Moscow, $113 \mathrm{p}$.

Margalef, R. 1958. Information theory in ecology. Gen. Syst. 3:36-37.

McNab, B.K. 1963. Bioenergetics and the determination of home range size. Amer. Natur. 97:133-140.

Mueggler, WF., and J.P. Blaisdell. 1951. Replacing wyethia with desirable forage species. J. Range Manage. 4:143-150.
Oosting, H.J. 1956. The study of plant communities. W.H. Freeman and Co. San Francisco, California. $440 \mathrm{p}$.

Sanders, K.D., B.E. Dahl, and G. Scott. 1980. Bite-count vs. fecal analysis for range animal diets. J. Range Manage. 33:146-149.

Shafi, M.I., and G.A. Yarranton. 1973. Diversity, floristic richness, and species evenness during a secondary (post-fire) succession. Ecology $54: 897-902$

Shaw, W.G. 1920. The cost of a squirrel and squirrel control. Washington State Coll. Agr. Exp. Sta. Pop. Bull. 11819 p.

Shaw, W.T. 1926. A short season and its effect and the preparation for reproduction by the Columbia ground squirrel. Ecology 7:136-139.

Shaw, W.T. 1945. Seasonal and daily activities of the Columbian ground squirrel at Pullman, Washington. Ecology 26:74-84.

Smith, C.C. 1940. The effect of overgrazing and erosion upon the biota of mixed-grass prairie of Oklahoma. Ecology 21:381-397.

Sparks, E.R., and J.C. Malechek. 1968. Estimating percent dry weights in diets using a microscope technique. J. Range Manage. 21:264-265.

Steele, R.R., R.A. Ryker, and J.A. Kittams. 1975. Forest habitat types of central Idaho. U.S. Forest Service, Intermt. For. and Range Exp. Sta. and Intermt. Region. $190 \mathrm{p}$.

Stoddart, L.A., A.D. Smith, and T.W. Box. 1975. Range management. 3rd Ed. McGraw-Hill Book Co. N.Y. 532 p.

Storr, G.M. 1961. Microscopic analysis of faeces, a technique for ascertaining the diet of herbivorous mammals. Aust. J. Biol. Sci. 14:157-164.

Thompson, R.A., P.H. Skabelund, N.C. Kulesza, and E.N. Dean. 1973. Soil-hydrologic. New Meadows Ranger District. U.S. Forest Service, Payette National Forest. 242 p. 